Original Research Paper

\title{
Monohibridization with Different Media Treatments on Fruit Flies (Drosophila melanogaster)
}

\author{
Msy Elsa Mayori Aurora ${ }^{1^{*}}$ dan Ika Oksi Susilawati ${ }^{1}$ \\ ${ }^{1}$ Program studi Biologi, FMIPA, Universitas Lambung Mangkurat, Jalan Jend A. Yani Km. 36, Banjarbaru 70713, \\ Indonesia
}

\author{
Article History \\ Received : May $21^{\text {th }}, 2020$ \\ Revised : July $20^{\text {th }}, 2020$ \\ Accepted : July $22^{\text {th }}, 2020$ \\ Published : July $27^{\text {th }}, 2020$ \\ *Corresponding Author: \\ Msy Elsa Mayori Aurora, \\ Fakultas Matematika dan Ilmu \\ Pengetahuan Alam, Universitas \\ Lambung Mangkurat \\ Kalimantan Selatan, Indonesia \\ Email: \\ mayorie520@gmail.com
}

\begin{abstract}
Drosophilla melanogaster is a modern experimental organism in the field of genetics because it has different phenotypic characters and looks real, easy to get, cheap (can be bred in bottles containing only fermented banana media) and has a breeding time that is not too long ( 2 weeks with maturation time) initial sexual ie 7 hours after exiting the pupa). This study aims to differentiate male and female fruit flies, create growth media for fruit fly culture and observe the phenotype ratio of F1 monohibrid crosses. The method used is the crossing of fruit flies by inserting male fruit flies and female fruit flies into a jam jar containing the medium using fermipan and not using fermipan. The phenotype and sex of fruit flies are formed from crossing of fruit flies. The results obtained in the form of fruit flies at most can grow on agar media and added corn flour with yeast. The medium needed by fruit flies to grow is a medium rich in protein and not much water dense. The media with corn flour is strong enough to resist thawing caused by larval activity, so that many larvae are found. Based on these conclusions, it can be continued observation of the fruit fly's politen chromosome in the next research.
\end{abstract}

Keywords: Monohibridization, Drosophila melanogaster, media

\section{Pendahuluan}

Salah satu ciri atau sifat makhluk hidup adalah mampu berkembang biak. Perkembangbiakan dapat terjadi melalui suatu perkawinan, yang akan menghasilkan suatu keturunan. Keturunan mewarisi sifat parental, salah satu sifat dikontrol oleh DNA di dalam inti maupun di luar inti. Pewarisan di luar inti sering dihubungkan dengan efek maternal. Sitoplasma menyediakan lingkungan tempat gen-gen mengambil peranan. Oleh karena itu induk betina diharapkan mempengaruhi peranan gen-gen tertentu, lebih banyak daripada induk jantan (Wahyuni, 2013).

Drosophila melanogaster merupakan jenis serangga biasa yang umumnya tidak berbahaya dan merupakan pemakan jamur yang tumbuh pada buah. Lalat ini merupakan lalat buah yang dapat dengan mudah berkembang biak. Contohnya dari satu perkawinan saja dapat menghasilkan ratusan keturunan, dan generasi yang baru dapat dikembangbiakkan setiap dua minggu. Drosophila melanogaster pada kondisi lingkunagan normal adalah organisme diploid dengan empat buah kromosom. Masing-masing kromosom mempunya empat pasang kromosom homolog keculai kromosom $\mathrm{X}$ dan kromosom Y (Oktary et al, 2015). Gen yang sifat jantan dan betina masing- masing tersebar diantara autosom dan terletak pada kromosom X. Ada kecenderungan betina yang kuat pada kromosom X. Dengan adanya satu kromosom X, maka akan memberikan 1,5 kecenderungan betina, sedangkan satu set autosom cenderung akan menjadi jantan, jadi perbansingannya 1,5 : 1 . Kromosom Y tidak menentukan jenis jantan ataupun kehidupan lalat Drosphila, akan tetapi kromosom Y diperlukan untuk menjaga fertilitas (Sisunandar, 2014).

Menurut Safitri \& Bachtiat (2017), D. melanogaster populer karena sangat mudah berkembang biak hanya memerlukan waktu dua minggu untuk menyelesaikan seluruh daur kehidupannya, mudah pemeliharaannya, serta memiliki banyak variasi fenotif yang relatif mudah diamati. Jumlah telur Drosophilla melanogaster yang dikeluarkan akan menurun apabila kekurangan makanan. Lalat buah dewasa yang kekurangan makanan akan menghasilkan larva berukuran kecil. Selain itu D. melanogaster memiliki manfaat dalam dunia kesehatan, seperti terapi penyakit menggunakan larva dari lalat buah yang biasa disebut dengan "Maggot Therapy”. Maggot therapy merupakan salah satu cara 
pengobatan alternative untuk mengobati luka borok atau korengan yang menahun.

Pada tahun 1910, T. H. Morgan yang merupakan sarjana Amerika, dapat memecahkan keanehan hukum Mendel yang mana diketahui bahwa kromosom mengandung banyak gen, dan mekanisme pewarisannya menyimpang dari hukum Mendel tersebut. Morganlah yang meletakkan dasar genetika kedua setelah Mendel (Dumalang \& Lengkong, 2011). Morgan memakai objek percobaan Drosophila melanogaster dan akhimya dinyatakan bahwa gen-gen bersama alel-alelnya yang terletak pada sepasang kromosorn homolog berkelompok, yang dinamakan kelompok berangkai. Kemudian hasil penyelidikan yang dilakukan pada makhluk lainnya dapat diambil kesimpulan bahwa banyaknya kelompok berangkai pada suatu individu itu ekuivalen dengan jumlah kromosom haploid dan individu yang bersangkutan. Oleh karena itu, ia mendapatkan hadiah nobel dalam Kedokteran dan Fisiologi pada tahun 1933 (Yatim, 2006).

Penelitian selanjutnya tentang Drosophila melanogaster dilakukan oleh Institut Teknologi California. Diteliti Drosophila melanogaster dengan memperhatikan warna matanya. Lalat yang normal berwarna merah, tetapi dari sekian banyak lalat ada lalat jantan yang bermata putih yang disebut mutan. Kemudian Morgan mengawinkan lalat jantan bermata putih dengan lalat betina normal (bermata merah). Diperoleh semua F1 baik jantan maupun betina bermata merah. Ketika lalatlalat F1 dikawinkan didapat keturunan F2 yang memperlihatkan perbandingan $3 / 4$ bermata merah: $1 / 4$ bermata putih, kecuali itu lalat-lalat F2 yang bermata merah adalah betina, dapat memberikan keturunan yang berbeda dari perkawinan resiprok (Suryo, 2008). Alasan menggunakan Drosophila melanogaster dalam percobaan adalah Drosophila melanogaster merupakan insekta yang memiliki jumlah kromosom yang sedikit, yaitu $2 \mathrm{n}=8$. Drosophila melanogaster memiliki siklus hidup yang pendek yaitu sekitar 10-12 hari, dengan menghasilkan telur yang banyak tiap kali Drosophila melanogaster betina bertelur, sehingga mudah dirawat dan mempunyai banyak karakter mutan. Menurut Agustina et al (2013) Drosophila melanogaster memiliki tiga pasang kromosom penting, yang mempunyai sistem kromosom XX / XY untuk penetapan kromosom seks, mempunyai kromosom raksasa pada kelenjar ludah dari larvanya, dan pada Drosophila melanogaster jantan tidak ditemukan crossing over atau pindah silang saat meiosis terjadi. Berdasarkan penjelasan tersebut maka perlunya dilakukan praktikum mengenai monohibridisasi pada lalat buah (Drosophila melanogaster) untuk mengetahui perbedaan lalat jantan dan betina.

Pemeliharaan untuk Drosophila melanogaster dapat dipergunakan bermacam-macam medium. Medium yang mula-mula dipergunakan ialah campuran antara pisang ambon dan tape ketela pohon dengan perbandingan 6:1. Medium yang tersedia itu dipakai selama lebih dari 15 tahun. Pada tahun 1984 mulai digunakan beberapa medium lain yang dicoba untuk dapat pula pemeliharaan Drosophila melanogaster (Dumalang \& Lengkong, 2011). Beberapa tahun terakhir ini telah digunakan medium baru, hal ini dikarenakan kualitas pisang dan tape yang tidak pernah seragam, sehigga dirasakan perlu untuk bisa memperoleh medium yang lebih dapat diandalkan. Medium baru yang dipakai merupakan modifikasi dari medium yang telah ada dan disesuaikan dengan kondisi di Indonesia (Hartaty, 2009). Tujuan dari penelitian ini adalah untuk membedakan lalat buah jantan dan betina, membuat media pertumbuhan untuk kultur lalat buah dan mengamati rasio fenotip F1 hasil persilangan monohibrid. Manfaat dari penelitian ini adalah untuk mengetahui perbedaan dari lalat buah jantan dan betina serta pertumbuhan yang baik pada lalat buah untuk berkemabang biak.

\section{Bahan dan Metode}

\section{Waktu dan Tempat}

Penelitian ini dilakukan pada bulan April-Mei 2019 di di Laboratorium Biologi Dasar, Fakultas Matematika dan Ilmu Pengetahuan Alam Universitas Lambung Mangkurat, Banjarbaru. Alat dan bahan yang digunakan adalah botol selai, autoklaf, gelas ukur, sudip, hot plate, lemari es, neraca analitik, gelas beaker, dan jarum pentul. Bahan yang digunakan adalah pisang, agar original, tepung gandum, alumunium foil, tepung jagung, air, karet gelang, serbuk khamir, kapas, eter, kertas label, kertas HVS, dan shield.

\section{Membuat Media Kultur Makanan Lalat Buah}

Medium makanan yang tertera pada tabel 1 diolah kemudian memasukkan ke dalam botol selai yang telah disediakan. Aluminium foil yang telah disediakan dipotong. Botol selai ditutup dengan aluminium foil kemudian dilubangi sehingga memungkinkan udara segar dapat keluar masuk ke dalam botol selai (aerasi tetap berlangsung). Separuh botol selai yang berisi media kemudian disterilisasi menggunakan autoklaf. Sebelum memasukkan lalat yang akan dikultur, media dalam botol selai dibubuhkan dengan sedikit serbuk khamir. Botol disimpan untuk mempercepat proses pendinginan. 
Tabel 1. Komposisi beberapa media untuk kultur Drosophila

\begin{tabular}{|c|c|c|c|}
\hline \multirow{2}{*}{$\begin{array}{c}\text { Unsur } \\
\text { Medium }\end{array}$} & \multicolumn{3}{|c|}{ Komposisi Medium Makanan } \\
\cline { 2 - 4 } & I & II & III \\
\hline Air & $47,8 \mathrm{~mL}$ & $74,3 \mathrm{~mL}$ & $77,5 \mathrm{~mL}$ \\
\hline Agar & $1,5 \mathrm{~g}$ & $1,5 \mathrm{~g}$ & - \\
\hline Pisang & $50 \mathrm{~g}$ & - & - \\
\hline $\begin{array}{c}\text { Tepung } \\
\text { Jagung }\end{array}$ & - & $10 \mathrm{~g}$ & - \\
\hline $\begin{array}{c}\text { Tepung } \\
\text { Gandum }\end{array}$ & - & - & $10,3 \mathrm{~g}$ \\
\hline
\end{tabular}

Ket: I: media I (agar + pisang)

II: media II (agar + tepung jagung)

III: media III (tepung gandum).

\section{Menghitung dan Memeriksa Persilangan Lalat Drosophila}

Eterisasi dilakukan dengan cara membasahi segumpal kapas yang telah disediakan dengan eter secukupnya. Kapas dimasukkan ke botol selai yang telah berisi lalat Drosophila yang akan digunakan untuk praktikum secepatnya dan ditutup kembali. Biarkan selama \pm 1 menit sampai semua lalat terbius. Kapas dan lalat Drosophila dikeluarkan dari botol. Lalat Drosophila yang telah terbius diletakkan diatas sehelai kertas HVS. Lalat yang mati dipisahkan dari lalat yang terbius. Eterisasi dilakukan lagi pada lalat yang hampir sadar selama beberapa detik. Lalat yang masih hidup dimasukkan ke dalam botol selai yang berisi kapas dan masing-masing media yang telah dibuat sebelumnya.

\section{Pengamatan}

Lalat yang terbius diletakkan di atas kertas HVS. Lalat diamati menggunakan kaca pembesar untuk membedakan jenis anatara jantan dan betina serta warna mata.

\section{Membuat Persilangan}

Dua pasang Drosophila melanogaster dimasukkan pada setiap botol selai yang telah berisi masing-masing medium kultur. Aluminium foil ditutup kembali kemudian dilubangi dengan jarum pentul sehingga memungkinkan udara segar dapat keluar masuk ke dalam botol selai (aerasi tetap berlangsung). Setelah seminggu seks dan fenotif lalat-lalat tersebut diamati. Hasil dicatat dalam tabel pengamatan

\section{Hasil dan Pembahasan}

\section{Pengamatan Monohibrid Drosophila}

Tabel berikut berisi tentang hasil pengamatan jumlah F1, warna mata, dan media mana yang paling banyak menghasilkan $D$. melanogaster. Media yang digunakan pada percobaan ini ialah agar + pisang, agar + tepung jagung, dan tepung jagung.
Tabel 2. Hasil Pengamatan Monohibrid pengulangan pertama (Tanpa Fermipan)

\begin{tabular}{|c|c|c|c|c|c|c|c|c|}
\hline \multirow[t]{2}{*}{$\begin{array}{l}\text { Me } \\
\text { dia }\end{array}$} & \multicolumn{2}{|c|}{$\begin{array}{c}\text { Jumlah } \\
\text { Lalat } \\
\text { Parental }\end{array}$} & \multicolumn{2}{|c|}{$\begin{array}{c}\text { Warna } \\
\text { Mata } \\
\text { Parental }\end{array}$} & \multicolumn{2}{|c|}{$\begin{array}{l}\text { Jumlah } \\
\text { Lalat F1 }\end{array}$} & \multicolumn{2}{|c|}{$\begin{array}{l}\text { Warna } \\
\text { Mata F1 }\end{array}$} \\
\hline & $\begin{array}{l}\text { Ja } \\
\text { nta } \\
\text { n } \\
\end{array}$ & $\begin{array}{l}\text { Be } \\
\text { tin } \\
\text { a }\end{array}$ & $\begin{array}{l}\text { Ja } \\
\text { nta } \\
\text { n }\end{array}$ & $\begin{array}{l}\text { Be } \\
\text { tin } \\
\text { a }\end{array}$ & $\begin{array}{l}\text { Ja } \\
\text { nta } \\
\text { n }\end{array}$ & $\begin{array}{l}\text { Be } \\
\text { tin } \\
\mathbf{a}\end{array}$ & $\begin{array}{l}\text { Ja } \\
\text { nta } \\
\text { n }\end{array}$ & $\begin{array}{l}\text { Be } \\
\text { tin } \\
\mathbf{a}\end{array}$ \\
\hline 1 & 2 & 3 & $\begin{array}{l}\mathrm{Me} \\
\mathrm{rah}\end{array}$ & $\begin{array}{l}\mathrm{Me} \\
\mathrm{rah}\end{array}$ & 0 & 1 & - & $\begin{array}{l}\text { Hit } \\
\text { am }\end{array}$ \\
\hline 2 & 2 & 2 & $\begin{array}{l}\mathrm{Me} \\
\mathrm{rah}\end{array}$ & $\begin{array}{l}\mathrm{Me} \\
\mathrm{rah}\end{array}$ & 1 & 1 & $\begin{array}{l}\mathrm{Me} \\
\mathrm{rah}\end{array}$ & $\begin{array}{l}\mathrm{Me} \\
\mathrm{rah}\end{array}$ \\
\hline 3 & 2 & 2 & $\begin{array}{l}\mathrm{Me} \\
\mathrm{rah}\end{array}$ & $\begin{array}{l}\mathrm{Me} \\
\mathrm{rah}\end{array}$ & 0 & 1 & - & $\begin{array}{l}\mathrm{Me} \\
\mathrm{rah}\end{array}$ \\
\hline
\end{tabular}

Hasil pengamatan monohibridisasi mengunakan media ditambahkan fermipan. Hasil yang ditunjukkan juga bervariasi setiap media yang berbeda. Media yang digunakan merupakan pengulangan pertama.

Tabel 3. Hasil Pengamatan Monohibrid pengulangan pertama (Ditambah Fermipan)

\begin{tabular}{|c|c|c|c|c|c|c|c|c|}
\hline \multirow[t]{2}{*}{$\begin{array}{l}\text { Me } \\
\text { dia }\end{array}$} & \multicolumn{2}{|c|}{$\begin{array}{c}\text { Jumlah } \\
\text { Lalat } \\
\text { Parental }\end{array}$} & \multicolumn{2}{|c|}{$\begin{array}{c}\text { Warna } \\
\text { Mata } \\
\text { Parental }\end{array}$} & \multicolumn{2}{|c|}{$\begin{array}{l}\text { Jumlah } \\
\text { Lalat F1 }\end{array}$} & \multicolumn{2}{|c|}{$\begin{array}{l}\text { Warna } \\
\text { Mata F1 }\end{array}$} \\
\hline & $\begin{array}{l}\text { Ja } \\
\text { nta } \\
\text { n }\end{array}$ & $\begin{array}{l}\text { Be } \\
\text { tin } \\
\mathbf{a}\end{array}$ & $\begin{array}{l}\text { Ja } \\
\text { nta } \\
\text { n }\end{array}$ & $\begin{array}{l}\text { Be } \\
\text { tin } \\
\text { a }\end{array}$ & $\begin{array}{l}\text { Ja } \\
\text { nta } \\
\text { n }\end{array}$ & $\begin{array}{l}\text { Be } \\
\text { tin } \\
\text { a }\end{array}$ & $\begin{array}{l}\text { Ja } \\
\text { nta } \\
\text { n }\end{array}$ & $\begin{array}{l}\text { Be } \\
\text { tin } \\
\text { a }\end{array}$ \\
\hline 1 & 3 & 3 & $\begin{array}{l}\mathrm{Me} \\
\mathrm{rah}\end{array}$ & $\begin{array}{l}\mathrm{Me} \\
\mathrm{rah}\end{array}$ & 0 & 0 & - & - \\
\hline 2 & 2 & 2 & $\begin{array}{l}\mathrm{Me} \\
\mathrm{rah}\end{array}$ & $\begin{array}{l}\mathrm{Me} \\
\mathrm{rah}\end{array}$ & 11 & 27 & $\begin{array}{l}\mathrm{Me} \\
\mathrm{rah}\end{array}$ & $\begin{array}{l}\text { Me } \\
\text { rah }\end{array}$ \\
\hline 3 & 1 & 3 & $\begin{array}{l}\mathrm{Me} \\
\mathrm{rah}\end{array}$ & $\begin{array}{l}\mathrm{Me} \\
\mathrm{rah}\end{array}$ & 0 & 1 & - & $\begin{array}{l}\mathrm{Me} \\
\mathrm{rah}\end{array}$ \\
\hline
\end{tabular}

Hasil dari pengamatan monohibridisasi mengunakan media tanpa fermipan. Media yang digunakan merupakan pengulangan kedua. Tabel ini menunjukkan bahwa hasil yang dimiliki setiap media berbeda.

Tabel 4. Hasil Pengamatan Monohibridisasi pengulangan ke dua (Tanpa Fermipan)

\begin{tabular}{|c|c|c|c|c|c|c|c|c|}
\hline \multirow[t]{2}{*}{$\begin{array}{l}\text { Me } \\
\text { dia }\end{array}$} & \multicolumn{2}{|c|}{$\begin{array}{c}\text { Jumlah } \\
\text { Lalat } \\
\text { Parental }\end{array}$} & \multicolumn{2}{|c|}{$\begin{array}{c}\text { Warna } \\
\text { Mata } \\
\text { Parental } \\
\end{array}$} & \multicolumn{2}{|c|}{$\begin{array}{l}\text { Jumlah } \\
\text { Lalat F1 }\end{array}$} & \multicolumn{2}{|c|}{$\begin{array}{l}\text { Warna } \\
\text { Mata F1 }\end{array}$} \\
\hline & $\begin{array}{l}\text { Ja } \\
\text { nta } \\
\text { n } \\
\end{array}$ & $\begin{array}{l}\text { Be } \\
\text { tin } \\
\mathbf{a} \\
\end{array}$ & $\begin{array}{l}\text { Ja } \\
\text { nta } \\
\text { n } \\
\end{array}$ & $\begin{array}{l}\text { Be } \\
\text { tin } \\
\mathbf{a} \\
\end{array}$ & $\begin{array}{l}\text { Ja } \\
\text { nta } \\
\text { n } \\
\end{array}$ & $\begin{array}{l}\text { Be } \\
\text { tin } \\
\text { a }\end{array}$ & $\begin{array}{l}\text { Ja } \\
\text { nta } \\
\text { n } \\
\end{array}$ & $\begin{array}{l}\text { Be } \\
\text { tin } \\
\text { a }\end{array}$ \\
\hline 1 & 2 & 2 & $\begin{array}{l}\mathrm{Me} \\
\mathrm{rah}\end{array}$ & $\begin{array}{l}\mathrm{Me} \\
\mathrm{rah}\end{array}$ & 0 & 0 & - & - \\
\hline 2 & 2 & 2 & $\begin{array}{l}\mathrm{Me} \\
\mathrm{rah} \\
\end{array}$ & $\begin{array}{l}\mathrm{Me} \\
\mathrm{rah}\end{array}$ & 0 & 0 & - & - \\
\hline 3 & 2 & 2 & $\begin{array}{l}\mathrm{Me} \\
\mathrm{rah} \\
\end{array}$ & $\begin{array}{l}\mathrm{Me} \\
\mathrm{rah}\end{array}$ & 0 & 0 & - & - \\
\hline
\end{tabular}


Tabel dibawah ini mennunjukkan hasil dari pengamatan monohibridisasi. Media yang digunakan merupakan tiga media berbeda dan ditambahkan fermipan. Media yang digunakan merupakan pengulangan kedua.

Tabel 5. Hasil Pengamatan Monohibridisasi pengulangan ke dua (Ditambah Fermipan)

\begin{tabular}{|c|c|c|c|c|c|c|c|c|}
\hline \multirow[t]{2}{*}{$\begin{array}{l}\text { Me } \\
\text { dia }\end{array}$} & \multicolumn{2}{|c|}{$\begin{array}{c}\text { Jumlah } \\
\text { Lalat } \\
\text { Parental }\end{array}$} & \multicolumn{2}{|c|}{$\begin{array}{c}\text { Warna } \\
\text { Mata } \\
\text { Parental }\end{array}$} & \multicolumn{2}{|c|}{$\begin{array}{l}\text { Jumlah } \\
\text { Lalat F1 }\end{array}$} & \multicolumn{2}{|c|}{$\begin{array}{l}\text { Warna } \\
\text { Mata F1 }\end{array}$} \\
\hline & $\begin{array}{l}\text { Ja } \\
\text { nta } \\
\text { n }\end{array}$ & $\begin{array}{l}\text { Be } \\
\text { tin } \\
\text { a }\end{array}$ & $\begin{array}{l}\text { Ja } \\
\text { nta } \\
\text { n }\end{array}$ & $\begin{array}{l}\text { Be } \\
\text { tin } \\
\text { a }\end{array}$ & $\begin{array}{l}\text { Ja } \\
\text { nta } \\
\text { n }\end{array}$ & $\begin{array}{l}\text { Be } \\
\text { tin } \\
\text { a }\end{array}$ & $\begin{array}{l}\text { Ja } \\
\text { nta } \\
\text { n }\end{array}$ & $\begin{array}{l}\text { Be } \\
\text { tin } \\
\text { a }\end{array}$ \\
\hline 1 & 2 & 2 & $\begin{array}{l}\mathrm{Me} \\
\mathrm{rah}\end{array}$ & $\begin{array}{l}\mathrm{Me} \\
\mathrm{rah}\end{array}$ & 0 & 1 & - & $\begin{array}{l}\mathrm{Me} \\
\mathrm{rah}\end{array}$ \\
\hline 2 & 2 & 2 & $\begin{array}{l}\mathrm{Me} \\
\mathrm{rah}\end{array}$ & $\begin{array}{l}\mathrm{Me} \\
\mathrm{rah}\end{array}$ & 3 & 22 & $\begin{array}{l}\mathrm{Me} \\
\text { rah }\end{array}$ & $\begin{array}{l}\mathrm{Me} \\
\mathrm{rah}\end{array}$ \\
\hline 3 & 2 & 2 & $\begin{array}{l}\mathrm{Me} \\
\mathrm{rah}\end{array}$ & $\begin{array}{l}\mathrm{Me} \\
\mathrm{rah}\end{array}$ & 1 & 3 & $\begin{array}{l}\mathrm{Me} \\
\text { rah }\end{array}$ & $\begin{array}{l}\mathrm{Me} \\
\mathrm{rah}\end{array}$ \\
\hline
\end{tabular}

Berikut merupakan hasil dari pengamatan monohibridisasi mengunakan media tanpa fermipan. Media yang digunakan merupakan pengulangan ketiga. Setiap media yang digunakan berbeda dengan hasil yang juga berbeda.

Tabel 6. Hasil Pengamatan Monohibrid pengulangan ketiga (Tanpa Fermipan)

\begin{tabular}{|c|c|c|c|c|c|c|c|c|}
\hline \multirow[t]{2}{*}{$\begin{array}{l}\text { Me } \\
\text { dia }\end{array}$} & \multicolumn{2}{|c|}{$\begin{array}{c}\text { Jumlah } \\
\text { Lalat } \\
\text { Parental }\end{array}$} & \multicolumn{2}{|c|}{$\begin{array}{c}\text { Warna } \\
\text { Mata } \\
\text { Parental }\end{array}$} & \multicolumn{2}{|c|}{$\begin{array}{l}\text { Jumlah } \\
\text { Lalat F1 }\end{array}$} & \multicolumn{2}{|c|}{$\begin{array}{l}\text { Warna } \\
\text { Mata F1 }\end{array}$} \\
\hline & $\begin{array}{l}\text { Ja } \\
\text { nta } \\
\text { n } \\
\end{array}$ & $\begin{array}{l}\text { Be } \\
\text { tin } \\
\text { a }\end{array}$ & $\begin{array}{l}\text { Ja } \\
\text { nta } \\
\text { n }\end{array}$ & $\begin{array}{l}\text { Be } \\
\text { tin } \\
\text { a }\end{array}$ & $\begin{array}{l}\text { Ja } \\
\text { nta } \\
\text { n } \\
\end{array}$ & $\begin{array}{l}\text { Be } \\
\text { tin } \\
\text { a } \\
\end{array}$ & $\begin{array}{l}\text { Ja } \\
\text { nta } \\
\text { n } \\
\end{array}$ & $\begin{array}{l}\text { Be } \\
\text { tin } \\
\text { a }\end{array}$ \\
\hline 1 & 1 & 1 & $\begin{array}{l}\mathrm{Me} \\
\mathrm{rah}\end{array}$ & $\begin{array}{l}\mathrm{Me} \\
\text { rah }\end{array}$ & 2 & 5 & $\begin{array}{l}\mathrm{Me} \\
\mathrm{rah}\end{array}$ & $\begin{array}{l}\mathrm{Me} \\
\mathrm{rah}\end{array}$ \\
\hline 2 & 1 & 1 & $\begin{array}{l}\mathrm{Me} \\
\mathrm{rah}\end{array}$ & $\begin{array}{l}\mathrm{Me} \\
\mathrm{rah}\end{array}$ & 0 & 1 & - & $\begin{array}{l}\mathrm{Me} \\
\mathrm{rah}\end{array}$ \\
\hline 3 & 1 & 1 & $\begin{array}{l}\mathrm{Me} \\
\mathrm{rah}\end{array}$ & $\begin{array}{l}\mathrm{Me} \\
\mathrm{rah}\end{array}$ & 1 & 3 & $\begin{array}{l}\text { Me } \\
\text { rah }\end{array}$ & $\begin{array}{l}\text { Me } \\
\text { rah }\end{array}$ \\
\hline
\end{tabular}

Tabel berikut berisi tentang hasil dari pengamatan monohibridisasi. Media ini ditambahkan fermipan. Media yang digunakan merupakan pengulangan ketiga.

Tabel 7. Hasil Pengamatan Monohibrid pengulangan ketiga (Ditambah Fermipan)

\begin{tabular}{|c|c|c|c|c|c|c|c|c|}
\hline \multirow[t]{2}{*}{$\begin{array}{l}\text { Me } \\
\text { dia }\end{array}$} & \multicolumn{2}{|c|}{$\begin{array}{c}\text { Jumlah } \\
\text { Lalat } \\
\text { Parental }\end{array}$} & \multicolumn{2}{|c|}{$\begin{array}{c}\text { Warna } \\
\text { Mata } \\
\text { Parental }\end{array}$} & \multicolumn{2}{|c|}{$\begin{array}{l}\text { Jumlah } \\
\text { Lalat F1 }\end{array}$} & \multicolumn{2}{|c|}{$\begin{array}{l}\text { Warna } \\
\text { Mata F1 }\end{array}$} \\
\hline & $\begin{array}{l}\text { Ja } \\
\text { nta } \\
\text { n }\end{array}$ & $\begin{array}{l}\text { Be } \\
\text { tin } \\
\text { a }\end{array}$ & $\begin{array}{l}\text { Ja } \\
\text { nta } \\
\text { n }\end{array}$ & $\begin{array}{l}\text { Be } \\
\text { tin } \\
\text { a }\end{array}$ & $\begin{array}{l}\text { Ja } \\
\text { nta } \\
\text { n }\end{array}$ & $\begin{array}{l}\text { Be } \\
\text { tin } \\
\text { a }\end{array}$ & $\begin{array}{l}\text { Ja } \\
\text { nta } \\
\text { n }\end{array}$ & $\begin{array}{l}\text { Be } \\
\text { tin } \\
\text { a }\end{array}$ \\
\hline 1 & 1 & 1 & $\begin{array}{l}\mathrm{Me} \\
\mathrm{rah}\end{array}$ & $\begin{array}{l}\mathrm{Me} \\
\text { rah }\end{array}$ & 0 & 0 & - & - \\
\hline
\end{tabular}

\begin{tabular}{lllllllll}
\hline 2 & 1 & 1 & $\begin{array}{l}\text { Me } \\
\text { rah }\end{array}$ & $\begin{array}{l}\text { Me } \\
\text { rah }\end{array}$ & 4 & 10 & $\begin{array}{l}\text { Me } \\
\text { rah }\end{array}$ & $\begin{array}{l}\text { Me } \\
\text { rah }\end{array}$ \\
\hline 3 & 1 & 1 & $\begin{array}{l}\text { Me } \\
\text { rah }\end{array}$ & $\begin{array}{l}\text { Me } \\
\text { rah }\end{array}$ & 4 & 5 & $\begin{array}{l}\text { Me } \\
\text { rah }\end{array}$ & $\begin{array}{c}\text { Me } \\
\text { rah }\end{array}$ \\
\hline
\end{tabular}

Hasil yang ditunjukkan merupakan media tanpa fermipan. Media yang digunakan merupakan pengulangan keempat. Dari tabel ini dapat dilihat hasil F1 dari lalat buah.

Tabel 8. Hasil Pengamatan Monohibridisasi pengulangan keempat (Tanpa Fermipan)

\begin{tabular}{|c|c|c|c|c|c|c|c|c|}
\hline \multirow[t]{2}{*}{$\begin{array}{l}\text { Me } \\
\text { dia }\end{array}$} & \multicolumn{2}{|c|}{$\begin{array}{c}\text { Jumlah } \\
\text { Lalat } \\
\text { Parental }\end{array}$} & \multicolumn{2}{|c|}{$\begin{array}{c}\text { Warna } \\
\text { Mata } \\
\text { Parental }\end{array}$} & \multicolumn{2}{|c|}{$\begin{array}{l}\text { Jumlah } \\
\text { Lalat F1 }\end{array}$} & \multicolumn{2}{|c|}{$\begin{array}{l}\text { Warna } \\
\text { Mata F1 }\end{array}$} \\
\hline & $\begin{array}{l}\text { Ja } \\
\text { nta } \\
\text { n }\end{array}$ & $\begin{array}{l}\text { Be } \\
\text { tin } \\
\text { a }\end{array}$ & $\begin{array}{l}\text { Ja } \\
\text { nta } \\
\text { n }\end{array}$ & $\begin{array}{l}\text { Be } \\
\text { tin } \\
\text { a }\end{array}$ & $\begin{array}{l}\text { Ja } \\
\text { nta } \\
\text { n }\end{array}$ & $\begin{array}{l}\text { Be } \\
\text { tin } \\
\text { a }\end{array}$ & $\begin{array}{l}\text { Ja } \\
\text { nta } \\
\text { n }\end{array}$ & $\begin{array}{l}\text { Be } \\
\text { tin } \\
\text { a }\end{array}$ \\
\hline 1 & 2 & 1 & $\begin{array}{l}\mathrm{Me} \\
\mathrm{rah}\end{array}$ & $\begin{array}{l}\mathrm{Me} \\
\mathrm{rah}\end{array}$ & 6 & 5 & $\begin{array}{l}\mathrm{Me} \\
\mathrm{rah}\end{array}$ & $\begin{array}{l}\mathrm{Me} \\
\mathrm{rah}\end{array}$ \\
\hline 2 & 2 & 1 & $\begin{array}{l}\mathrm{Me} \\
\mathrm{rah}\end{array}$ & $\begin{array}{l}\mathrm{Me} \\
\mathrm{rah}\end{array}$ & 2 & 1 & $\begin{array}{l}\text { Hit } \\
\text { am }\end{array}$ & $\begin{array}{l}\mathrm{Me} \\
\mathrm{rah}\end{array}$ \\
\hline 3 & 2 & 1 & $\begin{array}{l}\mathrm{Me} \\
\text { rah }\end{array}$ & $\begin{array}{l}\mathrm{Me} \\
\mathrm{rah}\end{array}$ & 4 & 6 & $\begin{array}{l}\mathrm{Me} \\
\mathrm{rah}\end{array}$ & $\begin{array}{l}\mathrm{Me} \\
\mathrm{rah}\end{array}$ \\
\hline
\end{tabular}

Pengamatan monohibridisasi mengunakan media ditambahkan fermipan pada tabel ini menunjukkan hasil yang bervariasi. Media yang digunakan merupakan pengulangan keempat. Pada tabel ini dapat dilihat hasil persilangan lalat buah jantan dan betina.

Tabel 9. Hasil Pengamatan Monohibridisasi pengulangan keempat (Ditambah Fermipan)

\begin{tabular}{|c|c|c|c|c|c|c|c|c|}
\hline \multirow[t]{2}{*}{$\begin{array}{l}\text { Me } \\
\text { dia }\end{array}$} & \multicolumn{2}{|c|}{$\begin{array}{c}\text { Jumlah } \\
\text { Lalat } \\
\text { Parental }\end{array}$} & \multicolumn{2}{|c|}{$\begin{array}{c}\text { Warna } \\
\text { Mata } \\
\text { Parental }\end{array}$} & \multicolumn{2}{|c|}{$\begin{array}{l}\text { Jumlah } \\
\text { Lalat F1 }\end{array}$} & \multicolumn{2}{|c|}{$\begin{array}{l}\text { Warna } \\
\text { Mata F1 }\end{array}$} \\
\hline & $\begin{array}{l}\text { Ja } \\
\text { nta } \\
\text { n }\end{array}$ & $\begin{array}{l}\text { Be } \\
\text { tin } \\
\text { a }\end{array}$ & $\begin{array}{l}\text { Ja } \\
\text { nta } \\
\text { n }\end{array}$ & $\begin{array}{l}\text { Be } \\
\text { tin } \\
\mathbf{a}\end{array}$ & $\begin{array}{l}\text { Ja } \\
\text { nta } \\
\text { n }\end{array}$ & $\begin{array}{l}\text { Be } \\
\text { tin } \\
\text { a }\end{array}$ & $\begin{array}{l}\text { Ja } \\
\text { nta } \\
\text { n }\end{array}$ & $\begin{array}{l}\text { Be } \\
\text { tin } \\
\text { a }\end{array}$ \\
\hline 1 & 2 & 1 & $\begin{array}{l}\mathrm{Me} \\
\mathrm{rah}\end{array}$ & $\begin{array}{l}\mathrm{Me} \\
\mathrm{rah}\end{array}$ & 2 & 1 & $\begin{array}{l}\text { Hit } \\
\text { am }\end{array}$ & $\begin{array}{l}\mathrm{Me} \\
\mathrm{rah}\end{array}$ \\
\hline 2 & 2 & 1 & $\begin{array}{l}\mathrm{Me} \\
\mathrm{rah}\end{array}$ & $\begin{array}{l}\mathrm{Me} \\
\mathrm{rah}\end{array}$ & 8 & 4 & $\begin{array}{l}\mathrm{Me} \\
\mathrm{rah}\end{array}$ & $\begin{array}{l}\mathrm{Me} \\
\mathrm{rah}\end{array}$ \\
\hline 3 & 2 & 1 & $\begin{array}{l}\mathrm{Me} \\
\text { rah }\end{array}$ & $\begin{array}{l}\mathrm{Me} \\
\mathrm{rah}\end{array}$ & 2 & 6 & $\begin{array}{l}\mathrm{Me} \\
\mathrm{rah}\end{array}$ & $\begin{array}{l}\mathrm{Me} \\
\mathrm{rah}\end{array}$ \\
\hline
\end{tabular}

Catatan:

1. Agar + pisang

2. Agar + Tepung Jagung

3. Tepung jagung

\section{Siklus Pertumbuhan Lalat Buah}

Drosophila melanogaster merupakan organisme eksperimen modern dalam bidang genetika kerena memiliki karakter fenotip yang berbeda dan terlihat nyata, mudah mendapatkannya, murah (dapat dibiakkan dalam 
botol yang hanya berisi media pisang yang difermentasi) dan mempunyai waktu perkembangbiakkan yang tidak terlalu lama ( 2 minggu dengan waktu pematangan seksual awal yaitu 7 jam setelah keluar dari pupa). Siklus hidup D.melanogaster pada suhu optimum untuk perkembangbiakkanya $\left(25^{\circ} \mathrm{C}\right)$ adalah : 0 jam $(0$ hari $)$, telur diletakkan 0-22 jam (0-1 hari), embrio 22 jam (1 hari), menetas dari telur (instar pertama) 47 jam ( 2 hari), instar kedua 70 jam (3 hari), instar ketiga 118 jam (5 hari), pembentukkan puparium 122 jam (5 hari), instar keempat 130 jam (5,5 hari), pupa 167 jam (7 hari), pigmentasi mata pupa 214 jam (9 hari), lalu imago keluar dari puparium dengan sayap yang melekuk dan berlipat yang merupakan stadium dewasa (Utami, 2011). Hal ini menunjukkan bahwa $D$. melanogaster mengalami metamorfosis sempurna selama siklus hidupnya. Walaupun fertilisasi biasanya dapat terjadi setelah 24 jam dalam stadium dewasa, peletakkan telur umumnya baru dilakukan setelah 2 hari dengan 50-75 telur setiap harinya (kemungkinan maksimum total 400-500 dalam 10 hari yang merupakan waktu generasi). Lalat dewasa dapat hidup selama 10 minggu (Raven et al, 2014).

Perbedaan Lalat Buah Betina dan Jantan

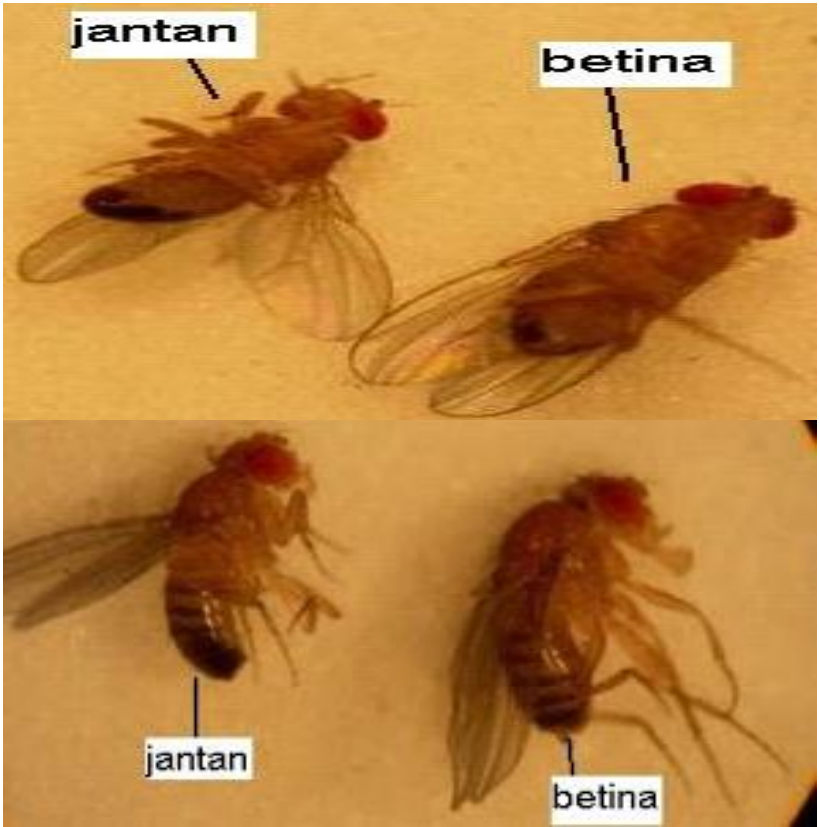

Gambar 1. Perbedaan Lalat Buah Jantan dan Betina (Sinau, 2010).

Pada pengamatan yang dilakukan cara membedakan lalat buah jantan dan betina adalah dengan melihat perbedaan morfologi antara lalat buah jantan dan lalat buah betina, walaupun tampak sekilas keduanya sangat mirip. Menurut Cames (2015) pada lalat buah jantan mempunyai ciri-ciri yaitu ujung abdomen membulat, jumlah abdomen atau sekat pada perut ada 5 buah, dan terdapat sisir kelamin berupa 10 buah rambut kaku berwarna hitam di permukaan distal tarsus terakhir kaki depan. Sedangkan pada lalat buah betina memiliki ciri-ciri yaitu ujung abdomen memanjang dan meruncing, jumlah abdomen atau sekat pada perut ada 7 buah, dan tidak memiliki sisir kelamin. Pada betina ujung abdomen yang memanjang dan meruncing itu ternyata berfungsi untuk menusuk buah muda berdaging dan untuk menyalurkan telurnya. Ujung abdomen tersebut mengandung bahan serupa lapisan tanduk. Selain itu, Menurut James (2001) terdapat perbedaan ciri pada lalat buah jantan dan betina yaitu ukuran jantan lebih kecil dan betinanya lebih besar. Berwarna kehitaman dan betinanya lebih putih dan terang. Terdapat struktur unik pada kaki depan jantan yaitu sexcomb dan tidak ada pada betina. Ukuran sayap jantannya lebih pendek dan betina relatif lebih panjang.

\section{Komposisi Media}

Penelitian ini secara umum menggunakan 3 media dengan 4 kali pengulangan menggunakan fermipan dan tidak menggunakan fermipan, yaitu media I (agar + pisang), media II (agar + tepung jagung), dan media III (tepung gandum). Adapun rincian medium I yang terbuat dari bahan baku 47,8 mL air, 1,5 gram agar, 50 gram pisang, medium II dengan komposisi bahan 74,3 mL air, 1,5 gram agar, 10 gram tepung jagung, sedangkan untuk medium III dengan komposisi 77,5 mL air dan 10,3 gram tepung gandum dan dibuat pengulangan masing-masing sebanyak 3 dibuat sama seperti media I-III namun dengan menambahkan fermipan secukupnya dan tidak ditambahkan fermipan. Kemudian media dipanaskan dan dimasukkan media yang ke dalam botol selai. Tutup botol selai dengan aluminium foil dan diberi lubang pada aluminium foil agar udara tetap dapat memasuki botol tersebut. Semua botol selai berisi media disterilkan dengan autoklaf. Kemudian tambahkan fermipan diatas media kultur secukupnya. Adapun fungsi dari media yang dicampur dengan agar-agar adalah untuk memadatkan media supaya menjadi keras. Menurut Safitri \& Bachtiat (2017) ragi atau fermipan mengandung mikroorganisme yang digunakan untuk fermentasi pada suatu media biakan. Penambahan fermipan ditujukan untuk meningkatkan kandungan nutrisi yang baik bagi pertumbuhan lalat buah dengan mempercepat penguraian nutrisi yang ada di dalam media. Selain itu fermipan digunakan untuk meningkatkan suhu di dalam botol karena proses oksidasi oleh khamir tersebut. Hal ini digunakan agar terjadi proses perombakan zat-zat dalam medium dalam proses fermentasi karbohidrat dan pisang yang akan menghasilkan glukosa dan gas yang diperlukan untuk pertumbuhan lalat buah, sedangkan komposisi yang lain digunakan untuk memberikan sumber nutrisi untuk lalat buah. 
Perkembangbiakan lalat buah pada percobaan ini menggunakan agar dan pisang, agar dan tepung jagung, dan agar dengan tepung gandum. Media yang digunakan ada yang ditambahkan ragi dan ada yang tidak ditambahkann. Hasil yang didapatkan ialah lalat buah paling banyak dapat tumbuh pada media agar dan tepung jagung yang ditambah dengan ragi. Media agar ditambah fermipan menghasilkan 1 betina, media agar ditambahkan tepung jagung dan fermipan menghasilkan 32 betina dan 3 jantan, agar ditambah tepung gandum dan fermipan menghasilkan 3 betina dan 1 jantan, sedangkan medium agar, pisang, tepung jagung dan gandum yang tidak ditambahkan fermipan tidak ada lalat buah yang tumbuh.

\section{Hasil Media yang Berbeda}

Hasil dari percobaan ini berbeda-beda setiap medianya, karena lalat buah membutuhkan rata-rata 10 hari untuk menyelesaikan siklus hidup mereka jika kultur dipertahankan pada $20^{\circ} \mathrm{C}-25^{\circ} \mathrm{C}$, telur diletakkan dalam 24 jam dan membutuhkan waktu hampir empat hari untuk kemunculan lalat baru. Medium dengan pisang tidak menghasilkan banyak lalat buah, karena buah-buahan yang dimakan lalat kaya akan campuran fruktosa, glukosa, sukrosa, dan karbohidrat lainnya, tetapi tidak kaya protein. Berdasarkan hasil percobaan ini membutuhkan tepung jagung dan tepung gandum mengandung protein lebih banyak. Menurut Mohapatra (2018) medium yang diperlukan oleh lalat buah untuk tumbuh ialah medium kaya protein dan padat tidak banyak air. Media dengan tepung jagung cukup kuat menahan pencairan yang disebabkan oleh aktivitas larva, sehingga larva banyak ditemukan. Sedangkan penelitian yang dilakukan oleh Wahyuni (2014) memiliki hasil terbaik dengan menggunakan media pisang dan agar-agar. Ini disebabkan oleh pisang dan agar-agar memiliki kandungan karbohidrat yang cukup untuk lalat buah. Karbohidrat memegang peranan penting dalam dalam pertumbuhan Drosophila karena karbohidrat merupakan komponen utama dalam buah-buahan dan merupakan bagian dari zat gizi utama penghasil energi

Penambahan fermipan juga menghasilkan lalat buah lebih banyak dibandingkan tidak menggunakan fermipan, karena fermipan mampu memberikan gizi pada pertumbuhan lalat buah. Penelitian yang dilakukan oleh Safitri \& Bachtiat (2017), ditemukan bahwa pengaruh ragi roti sebagai media pertumbuhan lalat buah yang dapat dilihat dari hasil rerata tertinggi sebesar 33,33 dan hasil rerata terkecil yaitu sebesar 4,6. Sehingga dapat dinyatakan bahwa pada penelitian ini ada pengaruh ragi roti sebagai media pertumbuhan lalat buah.

Fermipan menyediakan energi yang cukup tinggi antara lain seperti kalium, magnesium, fosfor, besi, dan kalsium. Telur yang dihasilkan oleh D. melanogaster betina akan menurun jika kekurangan makanan. Lalat buah dewasa akan menghasilkan larva yang berukuran kecil jika kekurangan makanan. Larvanya mampu membentuk pupa kecil, tetapi seringkali gagal berkembangbiak menjadi lalat dewasa. Makanan yang dimakan D. melanogaster dapat mempengaruhi jumlah telurnya. Selain itu D. melanogaster akan menghasilkan banyak telur apabila dalam keadaan ideal, dimana tersedia cukup ruang atau tidak terlalu padat, jika botol medium terlalu padat akan menyebabkan menurunnya produksi telurnya. D. melanogaster menyukai cahaya yang tidak terlalu gelap.

D. melanogaster memiliki genotif dengan viabilitas atau kemampuan hidup yang ditemukan oleh gen-gen dalam inti dan gen-gen diluar inti. Beberapa kriteria yang dapat digunakan untuk membedakan sifatsifat keturunan ialah induk betina memberi sumbangan lebih besar kepada keturunan daripada induk jantan sehingga sifat keturunan memiliki sifat-sifat dari induk betina. Persilangan resiprok menghasilkan keturunan yang berlainan juga, gen-gen terdapat dalam autosom sehingga persilangan resiprok menghasilkan keturunan yang sama. Segresi tidak ada dan perbandingan fenotip yang khas pada keturunan seperti prinsip Mendel, memberi petunjuk bahwa terdapat pewarisan diluar inti. Gen-gen dalam kromosom menempati lokus tertentu sehingga dapat dibuat peta kromosom, gen semacam ini tidak dijumpai pada pewarisan diluar inti, sehingga tidak dapat dibuat peta lokasi gen (Susanto, 2011).

D. melanogaster selain pada keadaan normal $(\mathrm{N})$ ditemukan ada beberapa strain yang merupakan hasil mutasi dan menghasilkan mutan-mutan yang berbeda dan keadaan normalnya. Mutasi pada $D$. melanogaster dapat terlihat dan fenotipnya seperti mutan warna mata, bentuk mata, bentuk sayap dan warna tubuh. Berdasarkan hal tersebut maka dikenal berbagai strain mutan antara lain $\mathrm{w}$ ( white), cl (clot), ca (claret), se (sepia), eym (eyemissing), cu (curled), tx (taxi), m (mature), dp (dumpy), dan vg (vestigial). Perbedaan-perbedaan fenotip yang nampak disebabkan karena telah terjadi perubahan pada genotip dengan keadaan normalnya, perbedaan ciri intraspesifik yang selanjutnya dikenal dengan sebutan strain. Mekanisme penggunaan sperma untuk pembuahan sel telur (vertilisasi) tidak terlalu sama pada semua jenis atau strain D. melanogaster. Jumlah sperma yang di transfer Drosophila jantan berkaitan dengan perbedaan strain, dengan demikian macam strain akan terkait dengan jumlah keturunan (Oktary et al, 2015).

\section{Kesimpulan}

Pada penelitian yang telah dilakukan dapat disimpulkan bahwa media yang paling bagus untuk pertumbuhan $D$. melanogaster adalah media agar yang dicampur tepung jagung. Medium yang diperlukan oleh lalat buah untuk tumbuh ialah medium kaya protein dan 
padat tidak banyak air. Media dengan tepung jagung cukup kuat menahan pencairan yang disebabkan oleh aktivitas larva, sehingga larva banyak ditemukan.

\section{Referensi}

Agustina E., Mahdi N. \& Herdanawati (2013). Perkembangan Metamorphosis Lalat Buah (Drosophilla melanogaster) pada Media Biakan Alami sebagai Referensi Pembelajaran pada Matakuliah Perkembangan Hewan. Jurnal Biotik. 1 (1): 1-7.

DOI: http://dx.doi.org/10.22373/biotik.v1i1.207

Carnes MU. (2015). The genomic basis of postponed senescence in Drosophila melanogaster. PLOS ONE. 10 (9): 1-22.

DOI:10.1371/journal.pone.0138569.

Dumalang S \& Lengkong M. (2011). Perilaku Kawin, Uji Respon dan Identifikasi Spesies Lalat Buah pada Belimbing, Ketapang dan Paria. Journal Eugenia. 12 (3): 193-202.

DOI: https://doi.org/10.35791/eug.17.3.2011.354 $\underline{3}$

Hartaty (2009). Penuntun Praktikum Genetika dan Evolusi. Jurusan Biologi FMIPA UNM, Makassar.

Hotimah H. Purwatiningsih \& Senjarini K. (2017). Deskripsi Morfologi Drosophilla melanogaster Normal (Diptera: Drosophilidae), Strain Sepia dan Plum. Jurnal Ilmu Dasar. 18 (1):55-60

DOI: https://doi.org/10.19184/jid.v18i1.3113

James HS. (2001). Drosophila melanogaster: The Fruit Fly. Fitzroy Dearborn Publishers, USA.

Mohapatra AK. (2018). Fecundity of Inbred Fruit Fly Drosophila melanogaster on Different Solid Culture Media: An Analysis. Journal of Applied and Natural Science. 10 (4):1109-1114.

DOI: $\underline{10.31018 / \mathrm{jans} . v 10 \mathrm{i} 4.1788}$

Oktary AP. Ridwan M. \& Armi (2015). Ekstrak Daun Kirinyuh (Eupatorium odoratum) dan Lalat Buah (Drosophila melanogaster). Serambi Akademica. 3 (2):335-342.

DOI: https://doi.org/10.32672/jsa.v7i2

Raven PH. Singer S. Mason KA. Johnson GB. \& Lasos

J. (2014). Biology 10 Edition. McGrow-Hill Higher Education, USA.
Safitri D. \& Bachtiat S. (2017). Pengaruh Penambahan Ragi pada Media terhadap Perkembang Biakan Drosophila melanogaster. Jurnal Biology Science \& Education. 6 (1): 45-52.

DOI: http://dx.doi.org/10.33477/bs.v6i1.132

Sinau (2010). Perbedaan Drosophila melanogaster (Lalat Buah) Jantan dan Betina. https://ayosinauonline.blogspot.com/2010/09/perb edaan-drosophila-melanogaster-lalat.html

Sisunandar. (2014). Penuntun Praktikum Genetika. UM, Purwekerto.

Suryo. (2008). Genetika Strata 1. UGM Press, Yogyakarta.

Susanto A. (2011). Catatan Kuliah Genetika. Penerbit ITB, Bandung.

Wahyuni S. (2013). Pengaruh Maternal terhadap Viabilitas Lalat Buah (Drosophila melanogaster Meigen) Strain Vestigial (vg). Skripsi. Universitas Jember, Jember.

Wahyuni ES. (2014). Pertumbuhan Lalat Buah (Drosophila sp.) pada berbagai Media dan Sumbangannya pada Pembelajaran Biologi di SMA. Jurnal Visi Ilmu Pendidikan. 12 (1):1-5.

DOI: http://dx.doi.org/10.26418/jvip.v12i1.10919

Yatim W. (2006). Genetika. Penerbit Tarsito, Bandung. 